\title{
LAST TWO HUNDRED INDIVIDUALS: REDISCOVERY OF SCILLA MESOPOTAMICA SPETA (HYACINTHACEAE), A THREATENED ENDEMIC SPECIES IN TURKEY
}

\author{
*ISMAIL EKER ${ }^{1}$, HASAN AKAN² \\ 1* Department of Biology, Faculty of Science and Literature, \\ Abant Izzet Baysal University \\ Gölköy, TR 14280, Bolu, Turkey \\ e-mail: tuliphunter2010@hotmail.com \\ 2 Department of Biology, Faculty of Science and Literature, \\ Harran University, Gölköy, Şanliurfa, Turkey
}

(Received: February 13, 2009. Accepted: December 1, 2009)

\begin{abstract}
In this paper, the rediscovery of endemic and long missing species, Scilla mesopotamica Speta which had been only known from the type gathering, is given. The species has not been collected again after Sintenis in 1888, whose specimens served Speta for description of the new taxon. In 2004, the authors found it in a steppic rocky area, near Halfeti in Şanliurfa province, South East Anatolia, Turkey. After analyzing Sintenis' original collection notes, they concluded that this area is identical with the type locality. S. mesopotamica has an extremely limited distribution and is represented by less than 200 specimens in the single known population that covers less than 50 $\mathrm{m}^{2}$. Taxonomy of the species, detailed description with illustrations, geographical distribution, habitat, ecology and status of IUCN extinction risk and some comments on conservation of the plant are also presented.
\end{abstract}

KEY WORDS: conservation, endemic, Hyacinthaceae, Scilla subgen. Scilla, threatened species, Turkey.

\section{INTRODUCTION}

The Hyacinthaceae family is represented by nine genera in the "Flora of Turkey" under Liliaceae sensu lato (Davis 1984). Among them, Scilla L. is represented by the 14 species in three subgenera with main distribution area in the Mediterranean and Irano-Turanian regions. Of all these, two species, Scilla leepii Speta and S. mesopotamica Speta, are endemic for Turkey and the endemism rate within the described region is thus above $14.28 \%$. Both endemic species of Scilla have a limited distribution around the Upper Euphrates and Mesopotamia. Generally, the species of genus Scilla live on limestone rocks, in grasslands, open woods, grassy slopes under shrubs, subalpine meadows, by streams, on rocky steppes and screes near permanent snows. The natural range of the genus Scilla stretches from the sea level up to $3050 \mathrm{~m}$ in Turkey (Mordak 1984).

For the treatment of genus Scilla in Turkey, Mordak (1984) accepted 14 "regular" species and added three other under the heading "species doubtfully or wrongly recorded". Later, Speta (1991) described two new species from the south of Turkey, namely S. dedea Speta and S. pruinosa Speta. Then, Özhatay (2000), in treatment in "Flora of
Turkey" suppl. II, indicated based on the relevant specimens of $S$. dedea and S. pruinosa that they could not be maintained as independent species. Therefore, both were reduced to synonymy of $S$. bifolia $\mathrm{L}$. Thus, the total number of Scilla species remains today unchanged with 14 species.

According to the Flora of Turkey (Mordak 1984), S. mesopotamica was first collected by Sintenis in 1888 from Rumkale, which is placed near Euphrates in the upper Mesopotamia. This place is about 5 kilometres to the north of Halfeti, a small town of Şanliurfa province. A large part of the land near Halfeti was submerged beneath the waters of a large hydro-electric project during the construction of GAP (Southeastern Anatolia Project). Although we had attempted several times between 2001 and 2003 to find the plant at this locality, we did not succeed. Moreover, many other extensive search attempts around the type locality of the plant either by foreign or Turkish botanists had failed. Particularly, during a project about the Turkish endemic plants supported by TUBITAK (Scientific and Technical Research Council of Turkey), much efforts were made to re-collect this species between 1993 and 1997, but all of these efforts were unsuccessful. The main reason for this 
was probably that the type locality of S. mesopotamica is within the centre of the Southeastern Anatolia Project and the probable natural habitats of the species were destroyed by the construction of dams and tunnels for the irrigation of plains. Therefore, the biological diversity, and especially the endemic plants, were strongly affected by this activity. Eventually, the species was found around the type locality during our fourth expedition and was reported by us in March 2004. The specimens were then checked against the description given in the "Flora of Turkey", and it was concluded that the identification was true. Thus, S. mesopotamica, which had not been collected for the past 116 years since its first collection, was rediscovered. As a result of these findings, this paper was prepared to re-describe the species owing to deficiencies in morphological description and to determine the present population condition. Besides, detailed description and illustrations, habitat, ecology, status of IUCN extinction risk and some comments on conservation of this poorly known endemic species are also given. Separately, anatomical properties of the species were studied by Satil and Akan (2006).

\section{MATERIALS AND METHODS}

Specimens of Scilla mesopotamica were collected from the type locality in March of 2004. Identification of the collected specimens was carried out using diagnostic key in the "Flora of Turkey and the East Aegean Islands"(Mordak 1984). In the research area, 50 specimens were examined and all of specimens were counted. Then, 20 specimens were collected as herbarium material and for ex-situ conservation. We compared them with the image of isotypes obtained from LU (Sweden). Unfortunately, we were not able to find any herbarium specimens in Turkish herbaria (AEF, AIBU, ANK, EGE, GAZI, HUB, ISTE, ISTF).

\section{RESULTS}

\section{Plant Description}

Scilla mesopotamica Speta in Naturk. Jahrb. Stadt Linz 22: 69 (1977) (Figs 1-3).

The following description is mainly based on our own observations, verifying those given by Mordak (1984) and adding some lacking features.

Bulb ovoid, 1-3×0.8-2.5 cm, outer tunic dark brown to blackish brown, inner dark reddish-pink. Leaves 2-5, synanthous, glabrous, white membranaceous at margins, margins smooth to slightly undulate, obtuse to acute at tip, blade prominently parallel veined, broadly linear to narrowly lanceolate, $8-40 \times 0.3-1.8 \mathrm{~cm}$, widened at maturity. Scapes 7-45×0.1-0.2 cm, stout, glabrous. Raceme 1 - to 6flowered, lax. Pedicels sub-erect, glabrous, 5-15 mm long, shorter than perianth segments at anthesis. Bracts bifid, 2-3 mm long, glabrous, whitish-blue. Perianth segments light blue with darker midrib, glabrous, 10-15×2-6 mm. Filaments filiform, whitish, glabrous, 7-9 mm long. Anthers dorsifixed, bluish, 3-4×1-1.2 mm; pollens greenish-blue. Ovary globose, glabrous; style 7-10 mm, glabrous; stigma punctate. Capsule globose to subglobose, $8-15 \times 8-12 \mathrm{~mm}$, glabrous. Seeds numerous, subglobose, $2-3 \times 1-2 \mathrm{~mm}$, yellowish-brown with whitish-yellow cylindrical caruncle.
Flowering and fruiting period: March to April.

Fl. and Fr.: 3-4.

Vernacular Turkish name: Mezopotamya sümbülü Phytogeographic region: Irano-Turanian element. Distribution of the species: Turkey (endemic) Type: [Turkey: C6 Urfa]: Rum-Kala'a (Halfeti), in parietibus rupium ad Euphratem, 21.3.1888, Sintenis 189 (holo. WU, iso. E, G, LD, LE, M, LU (photo!)), as S. cernua Delar.

Collection locality: [Turkey: C6 Şanliurfa]: Halfeti, 1. km from Halfeti-Şanliurfa road to Şanliurfa, $525 \mathrm{~m}$ a.s.1., 27. 03. $2004,37^{\circ} 14.331^{\prime} \mathrm{N}, 037^{\circ} 52.598^{\prime}$ E, Eker 699 and Akan; same place, 14. 04. 2007, Eker 1827 (AIBU, GAZI, HARRAN).

\section{Key to closely related Scilla species in Turkey}

1. Style 3-7 mm; tunics fuscous-violet

2. Perianth segments pale blue-violet, white at base; seeds subglobose, saffron yellow; scapes 2-5; leaves 6$-15(-22) \mathrm{cm} \times 4-9(-18) \mathrm{mm}$. S. ingridae

2. Perianth segments blue or whitish with dark midrib; seeds ovoid, pale brown with white cylindrical caruncle; scapes 1-2(-4); leaves (3-)3.5-7 cm $\times(2-) 4-6$ $\mathrm{mm}$............S. monanthos (including $S$. winogradowii)

1. Style 7-10 mm; outer tunics dark brown to blackishbrown, inner tunics dark reddish-pink ....S. mesopotamica

\section{Habitat and ecology}

Scilla mesopotamica grows on deep red soils derived from limestone bedrock, in steppic communities. Especially, it grows in stony and dry places, accompanied by some plants. Near the type locality they were: Ceterach officinarum DC., Minuartia tchihatchewii (Boiss.) Hand.-Mazz., Clypeola aspera Boiss, Geranium dissectum L., Geranium rotundifolium L., Geranium tuberosum L. subsp. tuberosum, Vicia palaestina Boiss., Amygdalus trichoamygdalus (Hand.-Mazz.) Woronow var. trichoamygdalus, Umbilicus horizontalis (Guss.) DC. var. intermedius (Boiss.) Chamberlain, Valeriana dioscoridis Sm., Lamium amplexicaule L., Salvia multicaulis Vahl, Asperula orientalis Boiss. \& Hohen.

\section{Conservation status}

According to the "Red Data Book of Turkish Plants" (Ekim et al. 2000) Scilla mesopotamica was categorized as "data deficient" (DD) because it was only known from type gathering of 1888 and it has not been collected again for many years.

The species was found by us at only one locality, next to the Şanliurfa-Halfeti road and the river Euphrates. It has a very limited distribution: it is represented by less than 200 individuals in the whole population that covers less than $50 \mathrm{~m}^{2}$. The area is grazed by animals, and is also being continuously destroyed by the construction of dams and tunnels for the irrigation of plains. Thus, the habitat of $S$. mesopotamica is under threat and its destruction would lead to a dramatic decrease of the abundance or even complete extinction of this species. Taking into account all these points, the species should be classified as "Critically Endangered" (CR) (criterion B1 a; IUCN 2001) and both it and the site should be protected. 


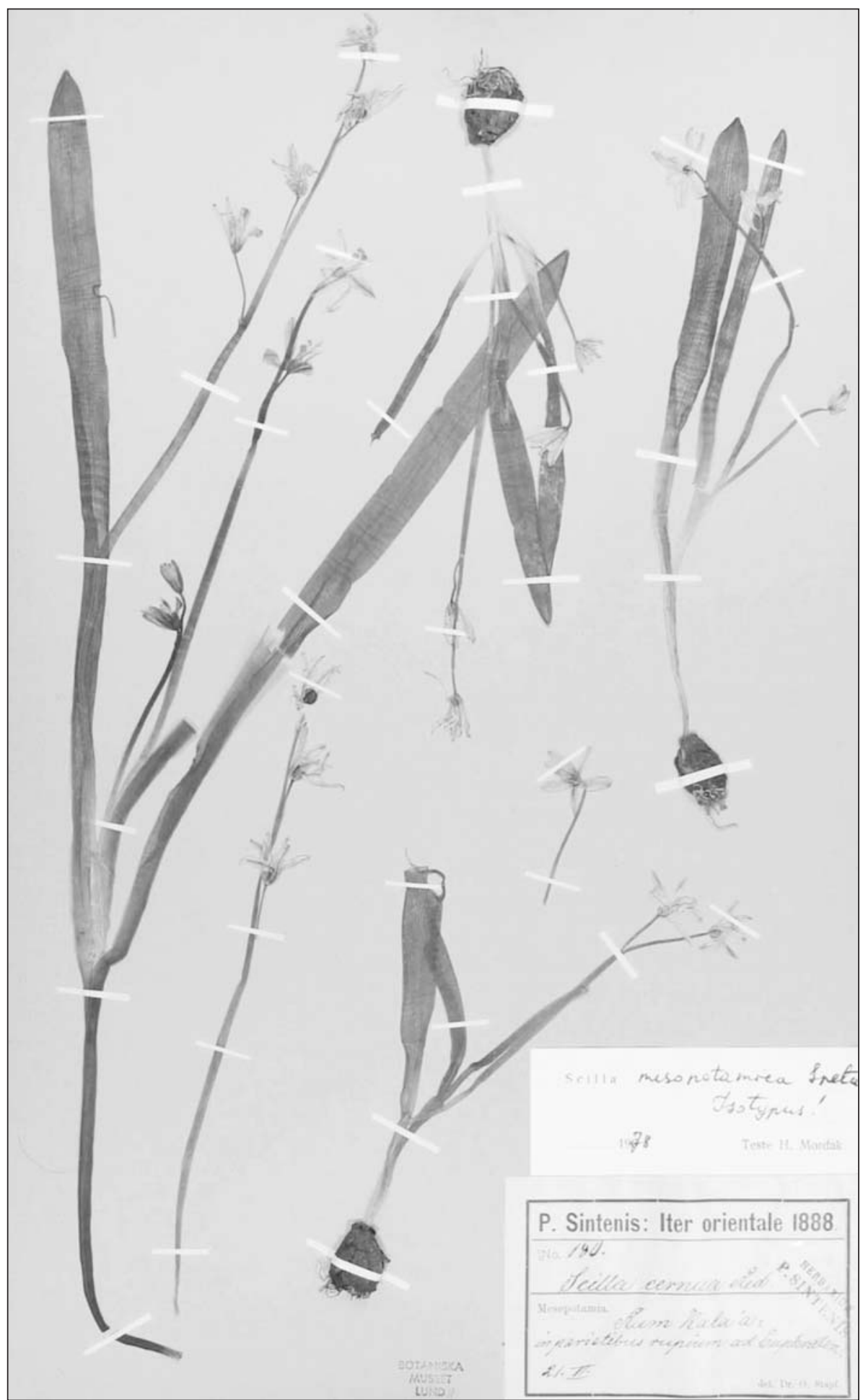

Fig. 1. The isotype of the Scilla mesopotamica Speta (LU herbarium, Sweden)

\section{DISCUSSION}

In this study, along with the rediscovery report on Scilla mesopotamica, a supplemented description based on individuals from the re-discovered population compared with the original description in the "Flora of Turkey" is given. Consequently, some differences between them are listed in Table 1. As can be seen from the table, some morphological characters of this species were not given in "Flora of Turkey" (Mordak 1984) such as: time of leaves' appearing, indumentum of leaves, scapes, pedicels, bracts and ovaries; leaf shape and width, scape length and width, anther cha- racters, length and width of capsule. Moreover, the first photos and illustrations of the plant are presented here

The bulbs of the Scilla mesopotamica that were collected during this study, were taken to cultivation in Abant Izzet Baysal University and Harran University Botanical garden for ex-situ conservation. In our opinion, this endemic species should be grown in botanical gardens and in this way protected. It is hoped that the trials will be successful and surplus plants and/or bulbs may also be available in the future for re-introduction. The plant has beautiful flowers and habit. Therefore, the species has potential economic value and may be used as ornamental plant in gardens. 


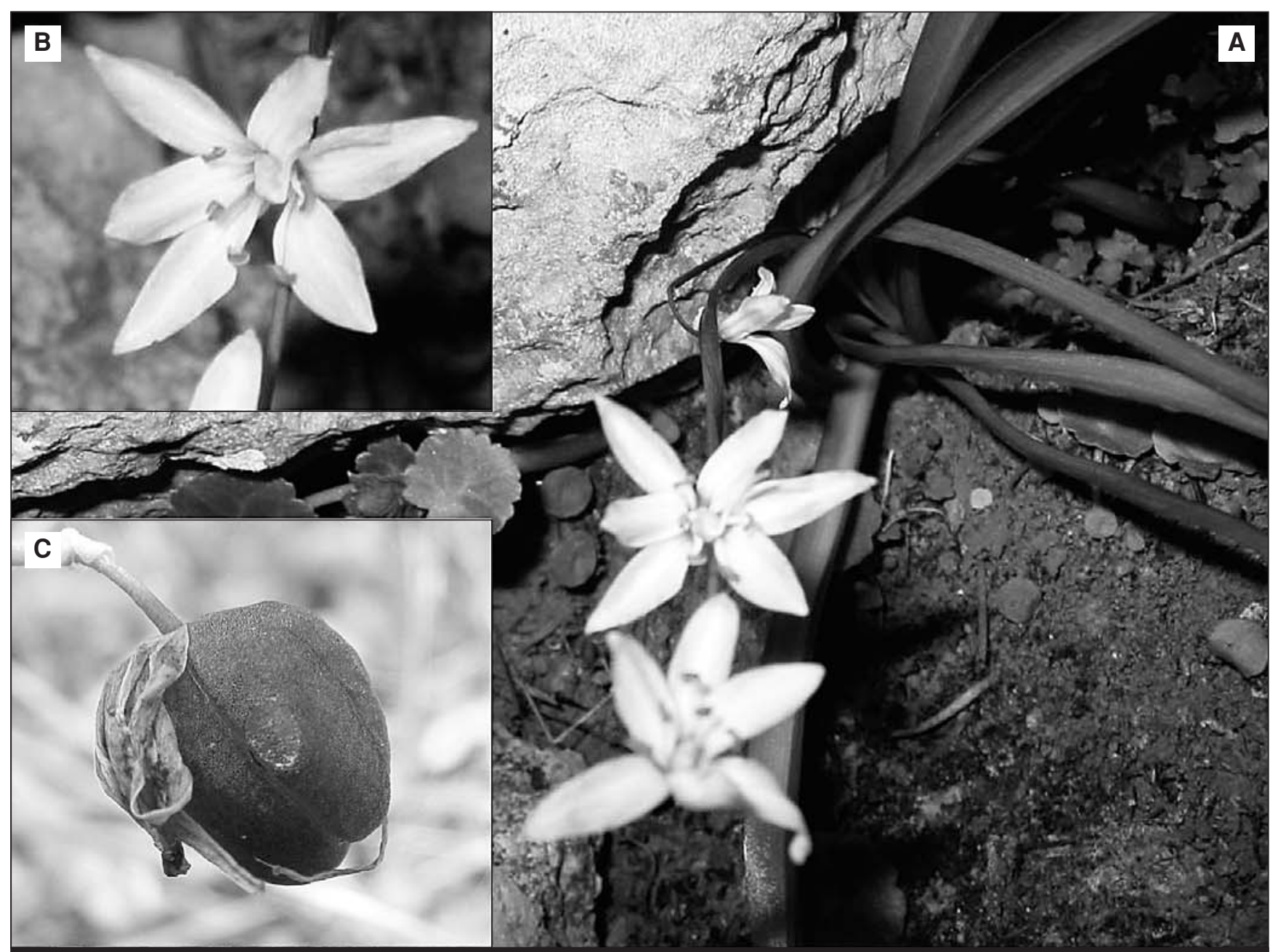

D

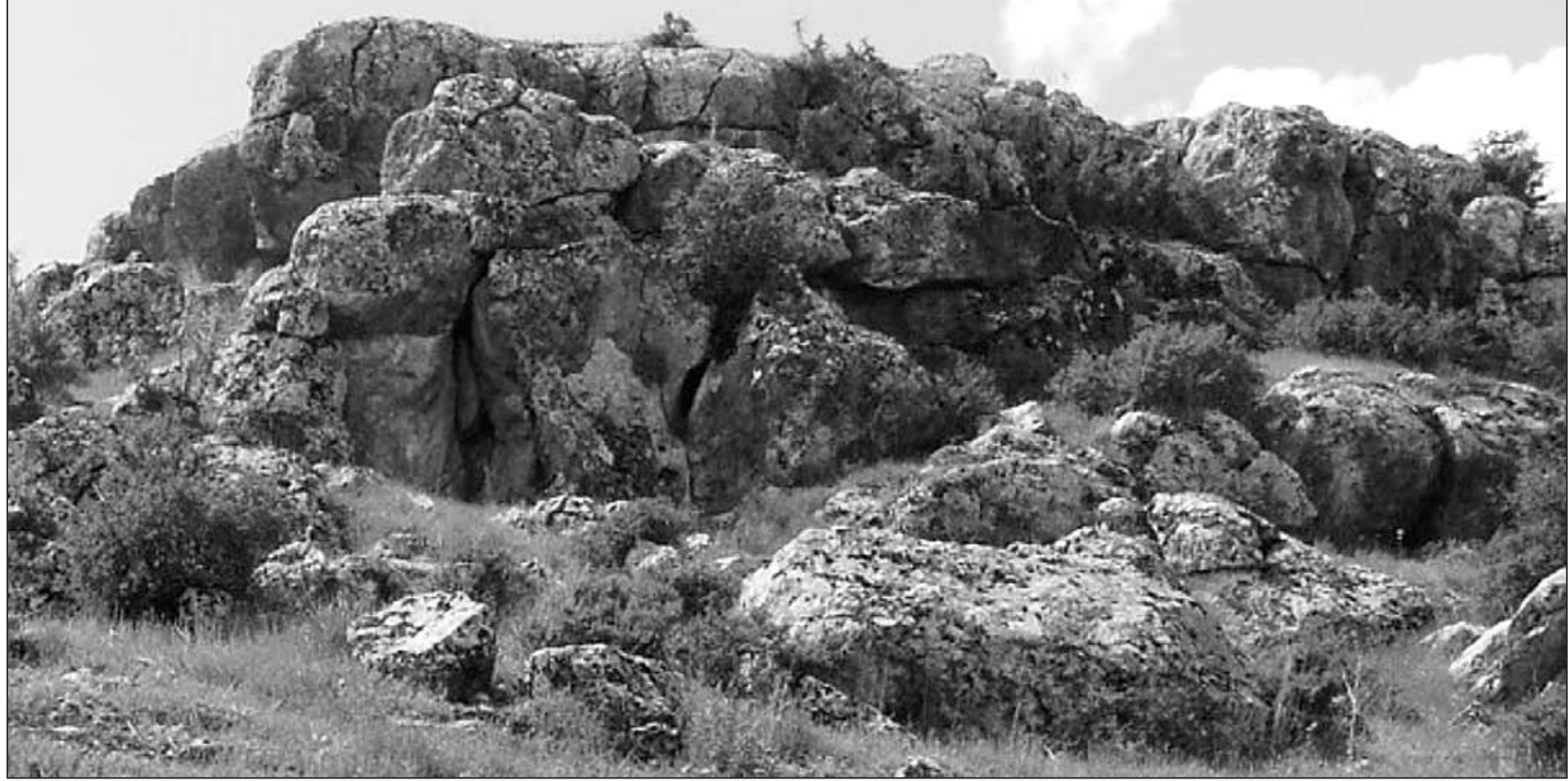

Fig. 2. Scilla mesopotamica Speta: A - general view in the natural habitat; B - flower; C - fruit; D - natural habitat (photo: Eker, 27. 03. 2004 and 14. 04. 2007). 


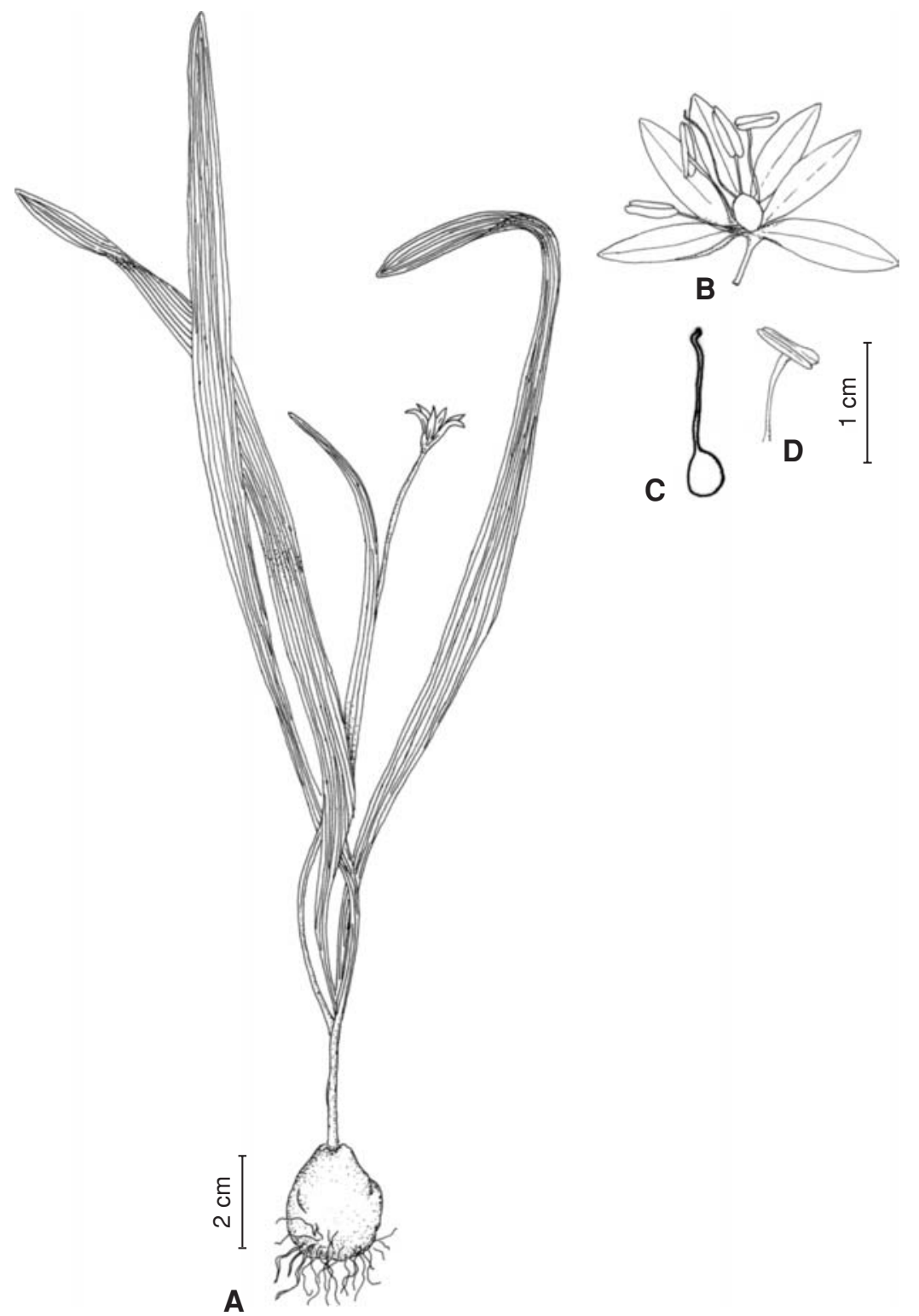

Fig. 3. Scilla mesopotamica Speta (drawn according to Eker 699): A - habit; B - perianth; C - pistil; D - stamen.

TABLE 1. A comparison of selected morphological characters of Scilla mesopotamica between descriptions given in the "Flora of Turkey" and in the present study.

\begin{tabular}{|c|c|c|}
\hline Morphological characters & $\begin{array}{l}\text { Flora of Turkey } \\
\text { (Mordak 1984) }\end{array}$ & $\begin{array}{l}\text { The findings of this study } \\
\text { (Eker and Akan 2010) }\end{array}$ \\
\hline Tunic colours & fuscous-violet & outer tunic dark brown to blackish brown, inner tunic dark reddish to pink \\
\hline The appearing of leaves & synanthous? or appearing before flowers? & synanthous (appearing at anthesis) \\
\hline Leaf shape & broadly linear & broadly linear to narrowly lanceolate \\
\hline Leaf indumentum & not indicated & glabrous \\
\hline Leaf margin & not indicated & white membranaceous at margins, margins smooth to slightly undulate \\
\hline Leaf length $\times$ width $(\mathrm{cm})$ & $15-34 \times 0.9-1.4$ & $8-40 \times 0.3-1.8$ \\
\hline Scape length $\times$ width $(\mathrm{cm})$ & to $36 \mathrm{~cm} \times$ [width not indicated] & $7-45 \times 0.1-0.2$ \\
\hline Scape indumentum & not indicated & glabrous \\
\hline Raceme & 1- to 5-flowered, lax & 1- to 6-flowered, lax \\
\hline Pedicel length (mm) & $5-21$ & $5-15$ \\
\hline Pedicel indumentum & not indicated & glabrous \\
\hline Bracts indumentum & not indicated & glabrous \\
\hline Perianth segments colour & pale blue with darker midrib & light blue with darker midrib \\
\hline Indumentum of perianth segments & not indicated & glabrous \\
\hline Anthers & not indicated & dorsifixed, $3-4 \times 1-1.2 \mathrm{~mm}$ \\
\hline Ovary indumentum & not indicated & glabrous \\
\hline Capsule length $\times$ width $(\mathrm{mm})$ & not indicated & $8-15 \times 8-12$ \\
\hline Capsule indumentum & not indicated & glabrous \\
\hline Seeds number and colour & not indicated & numerous, yellowish-brown with whitish-yellow cylindrical caruncle \\
\hline Seed length $\times$ width $(\mathrm{mm})$ & [length not indicated] $\times$ c.2 & $2-3 \times 1-2$ \\
\hline
\end{tabular}




\section{ACKNOWLEDGEMENTS}

We would like thank to Harran University (HÜBAK174) and TUBITAK (TBAG-2099) for financial support, curator of LU herbarium (Sweden) for providing the image of type specimen, and our colleague Hünkar Kayhan for language consulting.

\section{LITERATURE CITED}

DAVIS P.H. 1984. Liliaceae. In: Flora of Turkey and the East Aegean Islands, Davis P.H. (ed.), Edinburgh University Press, Edinburgh, pp. 8:67-358.

EKIM T., KOYUNCU M., VURAL M., DUMAN H., AYTAÇ Z., ADIGÜZEL N. 2000. Türkiye Bitkileri Kirmizi Kitabi
(Red Data Book of Turkish Plants), Türkiye Tabiatini Koruma Dernegi, Ankara, pp. 122. (in Turkish)

IUCN species survival commision. 2001. IUCN red list categories and criteria, ver. 3.1, pp. 1-18.

MORDAK E.V. 1984. Scilla L. In: Flora of Turkey and the East Aegean Islands, Davis P.H. (ed.), Edinburgh University Press, Edinburgh, pp. 8: 214-224.

ÖZHATAY N. 2000. Scilla L. In: Flora of Turkey and the east Aegean islands, Güner A., Özhatay N., Ekim T., Başer K.H.C. (eds), Edinburgh University Press, Edinburgh, pp. 11: 233.

SATIL F., AKAN H. 2006. Liliaceae Familyasindan Bazi Endemik ve Nadir Geofitler Üzerinde Anatomik Araştirmalar, Ekoloji 15: 21-27. (in Turkish)

SPETA F. 1991. Zwei neue Scilla-Arten (Hyacinthaceae) aus der S-Türkei. Willdenowia 21: 157-166. 